\title{
Resistance to different classes of drugs is associated with impaired apoptosis in childhood acute lymphoblastic leukemia
}

\author{
Amy Holleman, Monique L. den Boer, Karin M. Kazemier, Gritta E. Janka-Schaub, and Rob Pieters
}

Resistance of leukemic cells to chemotherapeutic agents is associated with an unfavorable outcome in pediatric acute lymphoblastic leukemia (ALL). To investigate the underlying mechanisms of cellular drug resistance, the activation of various apoptotic parameters in leukemic cells from 50 children with ALL was studied after in vitro exposure with 4 important drugs in ALL therapy (prednisolone, vincristine, L-asparaginase, and daunorubicin). Exposure to each drug resulted in early induction of phosphatidylserine (PS) externalization and mitochondrial trans- membrane ( $\left.\Delta \Psi_{\mathrm{m}}\right)$ depolarization followed by caspase-3 activation and poly(ADPribose) polymerase (PARP) inactivation in the majority of patients. For all 4 drugs, a significant inverse correlation was found between cellular drug resistance and (1) the percentage of cells with PS externalization ( $<.001<P<.008)$ and (2) the percentage of cells with $\Delta \Psi_{\mathrm{m}}$ depolarization $(.002<P<.02)$. However, the percentage of cells with caspase- 3 activation and the percentage of cells with PARP inactivation showed a significant inverse correlation with cellular resistance for pred- nisolone $(P=.001 ; \quad P=.001) \quad$ and L-asparaginase $(P=.01 ; P=.001)$ only. This suggests that caspase- 3 activation and PARP inactivation are not essential for vincristine- and daunorubicin-induced apoptosis. In conclusion, resistance to 4 unrelated drugs is associated with defect(s) upstream or at the level of PS externalization and $\Delta \Psi_{m}$ depolarization. This leads to decreased activation of apoptotic parameters in resistant cases of pediatric ALL. (Blood. 2003;102:4541-4546)

๑) 2003 by The American Society of Hematology

\section{Introduction}

Although combination chemotherapy has improved the prognosis of childhood acute lymphoblastic leukemia (ALL) over the last few decades, relapse still occurs in $20 \%$ to $30 \%$ of the cases. ${ }^{1}$ Cellular drug resistance measured at initial diagnosis is associated with an increased relapse risk and unfavorable clinical outcome in childhood ALL. ${ }^{2,3}$ In addition, the presence of adverse clinical prognostic factors such as older age ( $>10$ years) and pro-B and T-lineage immunophenotype have been shown to be associated with cellular resistance to drugs in children with ALL. ${ }^{4}$ These findings indicate that cellular drug resistance (measured in vitro) can be used as a tool to identify patients at higher risk of treatment failure.

Chemotherapeutic agents have been described to induce apoptosis in malignant cells. ${ }^{5}$ There are 2 major routes by which apoptosis can be induced: the extrinsic or death receptor-associated route and the intrinsic or mitochondrial route. Although there is disagreement concerning the role of the extrinsic route in chemotherapy-induced apoptosis, ${ }^{6,7}$ there is a general agreement regarding the importance of the intrinsic route. The intrinsic route can be subdivided into 3 general phases: ${ }^{8}$ (1) insult generation, (2) signal transduction, and (3) execution. During the insult generation phase, chemotherapeutic agents interact with and cause damage to their specific cellular targets. The signal transduction phase is the least-defined phase and is thought to involve integration of pro- and antiapoptotic signals. The relative abundances of pro- and antiapoptotic signals, that can be influenced by anticancer drugs, ${ }^{9}$ ultimately determines if the execution phase is initiated. ${ }^{10}$ The execution phase is initiated by release of cytochrome $\mathrm{c}$ and other polypeptides from the mitochon-

From the Department of Paediatric Oncology/Haematology, Erasmus MC/Sophia Children's Hospital, Rotterdam, The Netherlands; and the Cooperative Acute Lymphoblastic Leukemia (COALL) study group, Hamburg, Germany.

Submitted December 2, 2002; accepted August 10, 2003. Prepublished online as Blood First Edition Paper, August 14, 2003; DOI 10.1182/blood-2002-11-3612.

Reprints: Monique L. den Boer, Erasmus MC/Sophia Children's Hospital, drial intermembrane space. ${ }^{11}$ This release is accompanied by a dissipation of mitochondrial inner transmembrane potential $\left(\Delta \Psi_{\mathrm{m}}\right){ }^{12}$ Once released in the cytoplasm, cytochrome c interacts with Apaf-1 (apoptotic protease-activating factor-1), adenosine triphosphatedeoxyadenosine triphosphate (ATP/dATP), and procaspase-9 to form a complex known as the apoptosome. ${ }^{13}$ In the apoptosome, caspase-9 is activated which in turn activates effector caspases, like procaspase-3 and -7. ${ }^{14}$ The effector caspases cleave a number of structural and regulatory cellular proteins (eg, poly(ADP-ribose) polymerase [PARP], lamins) and are responsible for the typical morphologic and biochemical features of an apoptotic cell. ${ }^{15,16} \mathrm{~A}$ simplified overview of the events taking place during chemotherapyinduced apoptosis is given in Figure 1.

The fact that a point of convergence in the cellular response to cytotoxic drugs appears to be apoptosis and that leukemic cells display cross-resistance to drugs with different mechanisms of action has led to the hypothesis that cellular drug resistance may be related to defects in the apoptotic route. Aberrations at various levels of the apoptotic route have been linked to a drug-resistant phenotype in cell lines: absence of cytochrome c release, ${ }^{17,18}$ defective Apaf-1 activity, ${ }^{19-21}$ and caspase deficiency. ${ }^{22-24}$ However, the occurrence of apoptotic defects has not been studied in children with ALL. Therefore, the aim of this study was to determine whether cellular drug resistance is associated with defects in drug-induced apoptosis in pediatric ALL. To this aim, leukemic cells of 50 children with newly diagnosed ALL were exposed in vitro to 4 structurally unrelated drugs used in induction therapy of

Pediatric Oncology/Hematology, Rm Sp2456, Dr Molewaterplein 60, PO Box 2060, 3000 CB Rotterdam, The Netherlands; e-mail: m.I.denboer@erasmusmc.nl.

The publication costs of this article were defrayed in part by page charge payment. Therefore, and solely to indicate this fact, this article is hereby marked "advertisement" in accordance with 18 U.S.C. section 1734.

(C) 2003 by The American Society of Hematology 


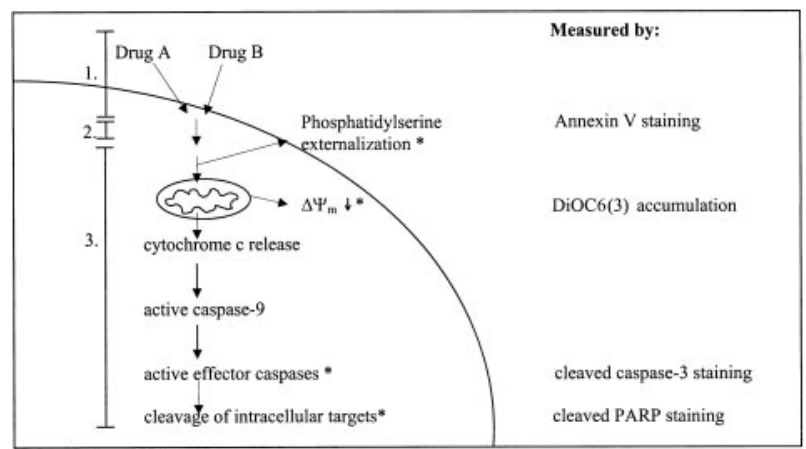

Figure 1. Simplified overview of the events taking place during drug-induced activation of apoptotic parameters. Drugs A and B represent 2 structurally unrelated drugs. Numbers 1,2 , and 3 refer to the 3 phases of the drug-induced apoptotic route as described in "Introduction": 1 indicates insult generation; 2, signal transduction; and 3, execution. Parameters with an asterisk $\left(^{*}\right)$ are measured in this study using flow cytometry; the right column indicates the detection method used.

ALL, and activation of various apoptotic parameters was evaluated (Figure 1).

\section{Materials and methods}

\section{Patient samples}

Bone marrow (BM) and/or peripheral blood (PB) were obtained from children with newly diagnosed ALL who entered the Sophia Children's Hospital or one of the hospitals participating in the German Cooperative Acute Lymphoblastic Leukemia (COALL) study. Within 24 hours after sampling, mononuclear cells were isolated by density gradient centrifugation with a Ficoll-Isopaque gradient (Lymphoprep $1.077 \mathrm{mg} / \mathrm{mL}$; Nycomed Pharma, Oslo, Norway). Cells were resuspended in culture medium consisting of RPMI 1640 Dutch modification without L-glutamine (Gibco BRL, Breda, The Netherlands) supplemented with $20 \%$ fetal calf serum (FCS; Integro, Zaandam, The Netherlands), $2 \times 10^{3} \mu \mathrm{mol} / \mathrm{L}$ L-glutamine, $900 \mu \mathrm{mol} / \mathrm{L}$ gentamycin (Gibco BRL), $100 \mathrm{IU} / \mathrm{mL}$ penicillin, $100 \mu \mathrm{g} / \mathrm{mL}$ streptomycin, $0.125 \mu \mathrm{g} / \mathrm{mL}$ fungizone (Gibco BRL), and $827 \mathrm{pmol} / \mathrm{L}$ insulin, $5 \times 10^{-3} \mathrm{~g} / \mathrm{L}$ transferrin, and $2.89 \times 10^{-5} \mu \mathrm{mol} / \mathrm{L}$ sodium selenite (ITS media supplement; Sigma Aldrich, Zwijndrecht, The Netherlands). If necessary, the lymphoid cells were further purified to at least $90 \%$ leukemic blasts by removing nonmalignant cells with immunomagnetic beads (DynaBeads, Dynal, Oslo, Norway)

\section{In vitro drug resistance assay}

In vitro drug resistance for daunorubicin (DNR; Cerubidine, RhônePoulenc Rorer, Amstelveen, The Netherlands), vincristine (VCR; TEVA Pharma, Mijdrecht, The Netherlands), L-asparaginase (ASP; Paronal, Christiaens, Breda, The Netherlands), and prednisolone (PRED; Bufa Pharmaceutical Products, Uitgeest, The Netherlands) was determined using the 4-day MTT (3-[4,5-dimethylthiazol-2-yl]-2,5-diphenyltetrazoliumbromide) assay as described previously by Pieters et al. ${ }^{25}$ Briefly, roundbottomed 96-well microculture plates were filled with $20 \mu \mathrm{L}$ of different dilutions of a drug and stored at $-20^{\circ} \mathrm{C}$. Six concentrations of each drug were tested in duplicate. The ranges of the final concentrations of these drugs were as follows: DNR: $0.002 \mu \mathrm{g} / \mathrm{mL}$ to $2.0 \mu \mathrm{g} / \mathrm{mL}$; VCR: 0.05 $\mu \mathrm{g} / \mathrm{mL}$ to $50 \mu \mathrm{g} / \mathrm{mL}$; ASP: $0.003 \mathrm{IU} / \mathrm{mL}$ to $10 \mathrm{IU} / \mathrm{mL}$; and PRED: 0.008 $\mu \mathrm{g} / \mathrm{mL}$ to $250 \mu \mathrm{g} / \mathrm{mL}$.

Aliquots of $80 \mu \mathrm{L}$ cell suspension $\left(2 \times 10^{6}\right.$ cells $\left./ \mathrm{mL}\right)$ were added to each well. Four wells contained $100 \mu \mathrm{L}$ culture medium without drugs or cells for blanking the plate reader and 8 wells contained $100 \mu \mathrm{L}$ culture medium with cells and without drug for measuring control cell viability. After incubating plates for 4 days at $37^{\circ} \mathrm{C}$ in a humidified incubator in $5 \%$ $\mathrm{CO}_{2}, 10 \mu \mathrm{L}$ MTT (5 mg/mL; Sigma) was added and the plates were incubated for an additional 6 hours. During these 6 hours, the living cells present in each well will reduce the yellow MTT tetrazolium salt to purple-blue formazan crystals. The formazan crystals were dissolved with $100 \mu \mathrm{L} 0.04 \mathrm{~N} \mathrm{HCl}$-isopropanyl alcohol (acidified isopropanol). The optical density (OD) of the wells, which is linearly related to cell number, ${ }^{26}$ was measured spectrophotometrically at $562 \mathrm{~nm}$. Leukemic cell survival (LCS) was calculated by the equation: $\mathrm{LCS}=\left(\mathrm{OD}_{\mathrm{day} 4}\right.$ treated well/mean $\mathrm{OD}_{\text {day } 4}$ control wells) $\times 100 \%$. The drug concentration lethal to $50 \%$ of the ALL cells, the $\mathrm{LC}_{50}$ value, was used as a measure for cellular drug resistance. MTT-assay results were only used if the drug-free control wells contained at least $70 \%$ leukemic cells after 4 days of culture.

\section{In vitro drug exposure for measuring apoptotic features}

Fresh leukemic cells $\left(2.0 \times 10^{6}\right.$ cells $\left./ \mathrm{mL}\right)$ with a purity of at least $90 \%$ leukemic blasts were cultured in the presence of drugs at $37^{\circ} \mathrm{C}$ in a humidified incubator in $5 \% \mathrm{CO}_{2}$. The ranges of the final drug concentrations were as follows: PRED: $0.061 \mu \mathrm{g} / \mathrm{mL}$ to $250 \mu \mathrm{g} / \mathrm{mL}$; VCR: 0.195 $\mu \mathrm{g} / \mathrm{mL}$ to $50 \mu \mathrm{g} / \mathrm{mL}$; ASP: $0.016 \mathrm{IU} / \mathrm{mL}$ to $10 \mathrm{IU} / \mathrm{mL}$; and DNR: 0.008 $\mu \mathrm{g} / \mathrm{mL}$ to $2.0 \mu \mathrm{g} / \mathrm{mL}$.

\section{Measurement of aberrant phosphatidylserine externalization on the outer cell membrane}

During the early stages of apoptosis, phosphatidylserine (PS) is translocated from the inner side of the plasma membrane to the outer leaflet of the cell membrane. Annexin $\mathrm{V}$ is a $\mathrm{Ca}^{2+}$-dependent phospholipid-binding protein with high affinity for PS and can therefore be used to detect apoptotic cells. Leukemic cells were resuspended in $200 \mu$ L Annexin V-Alexa 488 Reagent (Nexins Research BV, Kattendijke, The Netherlands) and incubated for 15 minutes at $4^{\circ} \mathrm{C}$. A total of 5000 events was analyzed by flow cytometry (FACSCalibur, Becton Dickinson, Erembodegem, Belgium). Drug-induced apoptosis was calculated according to the following formula: percentage of apoptotic cells $=100 \% \times(\mathrm{D}-\mathrm{C}) /(100-\mathrm{C})$, where $\mathrm{D}$ represents the percentage of Annexin V-positive cells in the presence of a drug and $\mathrm{C}$ is the percentage of Annexin $\mathrm{V}$-positive cells in the absence of a drug (spontaneous apoptosis). The intra-assay coefficient of variation for measurements of PS externalization was $3.4 \%$.

\section{Detection of apoptosis-associated alterations in $\Delta \Psi_{m}$}

Disruption of $\Delta \Psi_{\mathrm{m}}$ was determined using 3,3'-dihexyloxacarbocyanine iodide (DiOC6(3); Molecular Probes, Eugene, OR), a lipophilic cationic dye that accumulates in the mitochondrial matrix driven by $\Delta \Psi_{\mathrm{m}} \cdot{ }^{27}$ Loss of $\Delta \Psi_{\mathrm{m}}$ was visualized as a reduction in the signal in the FL1 channel. Leukemic cells were incubated in $200 \mu \mathrm{L}$ phosphate-buffered saline (PBS) containing $40 \mathrm{nM}$ DiOC6(3) solution and incubated in a humidified incubator for 30 minutes at $37^{\circ} \mathrm{C}$ in $5 \% \mathrm{CO}_{2}$. A total of 5000 events was analyzed by flow cytometry. Percentage of cells with decreased mitochondrial transmembrane depolarization $\left(\Delta \Psi_{\mathrm{m}} \downarrow\right)$ was calculated with the following formula: $100 \% \times(\mathrm{D}-\mathrm{C}) /(100-\mathrm{C})$, where $\mathrm{D}$ represents the percentage of cells with reduced DiOC6(3) accumulation in drug-treated samples and $\mathrm{C}$ represents the percentage of cells with reduced DiOC6(3) accumulation in untreated samples. The intra-assay coefficient of variation for measurements of disruption of $\Delta \Psi_{\mathrm{m}}$ was $4.5 \%$.

\section{Measurement of caspase- 3 and PARP cleavage}

Leukemic cells were fixed using $2 \%$ (vol/vol) $37 \%$ formaldehyde solution in $100 \%$ acetone. Fixed cells were washed twice with PBS/0.1\% bovine serum albumin (BSA) and incubated with an antibody directed against cleaved caspase-3 (Cell Signalling Technology, Beverly, MA) or cleaved PARP (Cell Signalling Technology) at room temperature for 30 minutes. Both antibodies recognize an epitope exposed only when both proteins are cleaved during apoptosis. Subsequently, cells were washed and incubated with fluorescein isothiocyanate (FITC)-conjugated rabbit antirabbit $\mathrm{F}(\mathrm{ab}$ ') (DAKO, Glostrup, Denmark) for caspase-3 and FITC-conjugated pork antimouse $\mathrm{F}\left(\mathrm{ab} \mathrm{b}_{2}\right.$ (DAKO) for PARP at room temperature for 30 minutes. A total of 5000 events was measured by flow cytometry. Caspase-induced PARP cleavage leads to PARP inactivation, ${ }^{15}$ hence we measured caspase- 3 activation and PARP inactivation. The percentage of cells with caspase-3 activation or PARP inactivation was determined with the following 
formula: $100 \% \times(\mathrm{D}-\mathrm{C}) /(100-\mathrm{C})$, where $\mathrm{D}$ represents the percentage of cells that stain positive for the antibody in drug-treated samples, and $\mathrm{C}$ is the percentage of cells that stain positive for the antibody in untreated samples. Intra-assay variation of caspase- 3 and PARP cleavage measurements was $11.2 \%$ and $11.8 \%$, respectively.

\section{Statistics}

Correlations between different apoptotic parameters as well as between the $\mathrm{LC}_{50}$ values and apoptotic parameters were calculated using the Spearman rank $\left(r_{s}\right)$ correlation test. Statistical tests were performed at a 2-tailed significance level of 0.05 .

\section{Results}

Time-dependent induction of apoptotic parameters was studied in 5 children with ALL in order to determine the most suitable time point for testing a larger group of children with ALL. In vitro exposure to each of the 4 drugs tested caused a time-dependent activation of apoptotic parameters in ALL cells as assessed by an increase of cells with PS externalization, $\Delta \Psi_{\mathrm{m}}$ depolarization, caspase- 3 activation, and PARP inactivation (Figure 2). In only one patient were sufficient cells available to perform an extensive concentration series. The data indicated a concentration-dependent increase in the activity of all apoptotic parameters (data not shown).

Although exposure to all 4 drugs resulted in activation of similar apoptotic parameters, a difference in apoptosis kinetics was observed. Whereas daunorubicin and vincristine trigger a relatively fast activation of apoptotic parameters, L-asparaginase and prednisolone consistently induced apoptosis more slowly (Figure 2). After 18 hours of daunorubicin or vincristine exposure the mean percentage of cells with PS externalization in the 5 ALL samples is $52 \% \pm 23 \%$ and $36 \% \pm 21 \%$, respectively. In contrast, the mean percentage of cells with PS externalization after 18 hours of L-asparaginase and prednisolone exposure was $20 \% \pm 15 \%$ and $21 \% \pm 31 \%$ compared with $30 \% \pm 18 \%$ and $19 \% \pm 19 \%$, respectively, after 42 hours. The 2 types of kinetics could be confirmed in subsequent experiments; the mean percentage of cells with PS externalization in the 50 patients measured in this study after 18 hours of daunorubicin or vincristine treatment are $60 \% \pm 24 \%$ and $42 \% \pm 25 \%$, respectively, compared with $31 \% \pm 19 \%$ and $30 \% \pm 30 \%$ after 42 hours L-asparaginase and prednisolone exposure, respectively. To be able to study the relationship between apoptosis and cellular drug resistance in a large group of patients, activation of apoptotic parameters was measured after 18 hours of incubation with daunorubicin and vincristine and after 42 hours of incubation with $\mathrm{L}$-asparaginase and prednisolone in further experiments.

Figure 3 shows that the percentage of cells with PS externalization is proportional to the percentage of cells with reduction in mitochondrial transmembrane potential $\left(\mathrm{r}_{\mathrm{s}}=0.75, P<.001\right)$, caspase-3 activation $\left(\mathrm{r}_{\mathrm{s}}=0.72, P<.001\right)$, and the percentage of cells with PARP inactivation $\left(r_{\mathrm{s}}=0.67, P<.001\right)$. Significant correlations were also found when analyzing data from each of the 4 drugs separately (Table 1). The slopes of the regression lines in Figure 3A-C are $\mathrm{a}=0.75, \mathrm{a}=0.52$, and $\mathrm{a}=0.44$, respectively. The closer the slope of the regression line approaches $\mathrm{a}=1.0$, the closer the event probably follows after PS externalization. This indicates that upon drug exposure, PS externalization and $\Delta \Psi_{\mathrm{m}}$ depolarization are early events, whereas caspase-3 activation and PARP inactivation are occurring relatively later.

Large interindividual variability in the extent of drug-induced activation of apoptotic parameters was observed between patients. For instance, prednisolone-induced PS externalization after 42 hours ranged between $-26 \%$ and $86 \%$ (median: 27\%). Figure 4 and Table 2 show for each individual drug highly significant inverse correlations between the $\mathrm{LC}_{50}$ and (1) the percentage of cells with PS externalization and (2) the percentage of cells with $\Delta \Psi_{\mathrm{m}}$ depolarization. However, caspase-3 activation and PARP inactivation showed a less-consistent inverse correlation pattern with cellular drug resistance. A significant inverse correlation between cellular drug resistance and the percentage of cells with caspase- 3 activation was observed for prednisolone $\left(\mathrm{r}_{\mathrm{s}}=-0.60\right.$, $P=.001)$ and L-asparaginase $\left(\mathrm{r}_{\mathrm{s}}=-0.46, P=.01\right)$ but not for
A

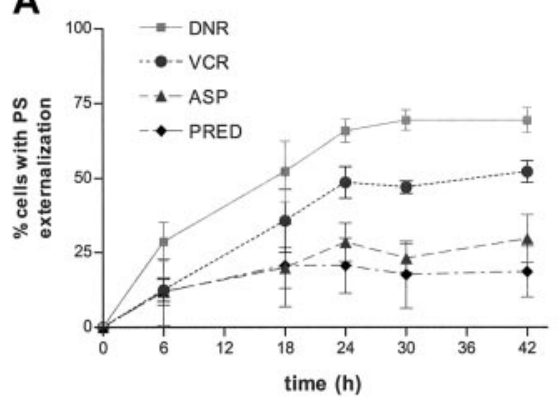

C

Figure 2. Time-dependent drug-induced apoptosis in ALL. Freshly isolated ALL cells were cultured in the presence of $2.0 \mu \mathrm{g} / \mathrm{mL}$ daunorubicin (DNR; $\square$ ), $50 \mu \mathrm{g} / \mathrm{mL}$ vincristine (VCR; $\bullet$ ), $10 \mathrm{IU} / \mathrm{mL}$ L-asparaginase (ASP; $\Delta$ ), or $250 \mu \mathrm{g} / \mathrm{mL}$ prednisolone (PRED; ) for the indicated time points. Drug-induced PS externalization (A), mitochondrial transmembrane disruption (B), caspase-3 activation $(\mathrm{C})$, and PARP inactivation (D) were determined by flow cytometry and calculated by the formula described in "Materials and methods." Results are expressed as mean \pm SD of 5 patients with ALL.

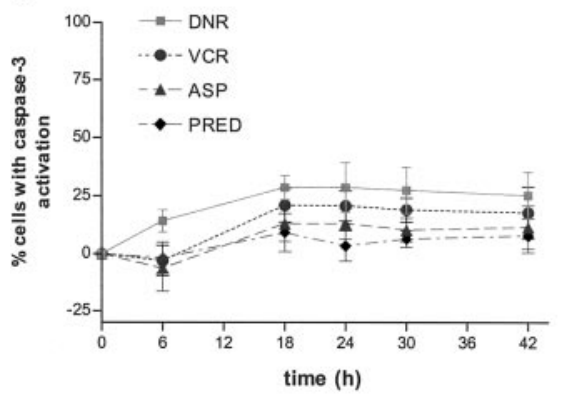

time (h)
B

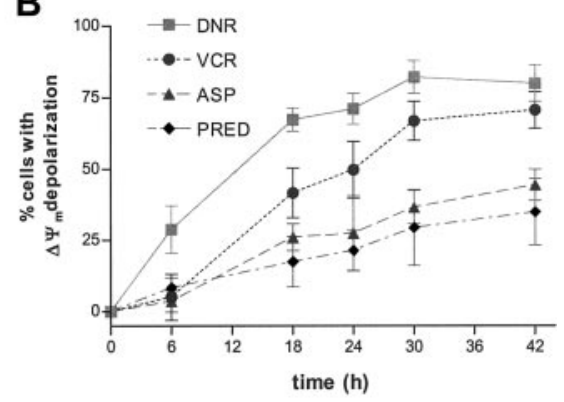

D

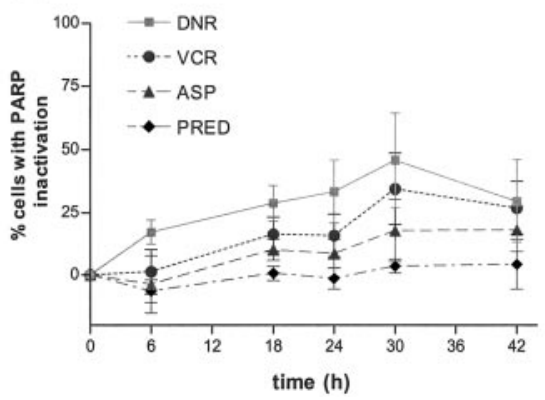
the (h) 
A

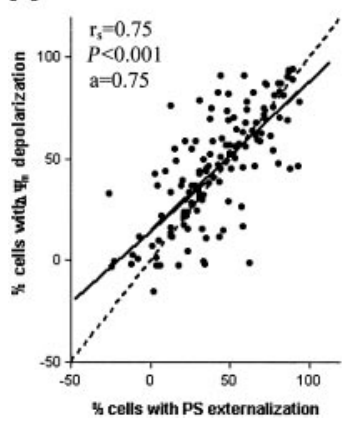

B

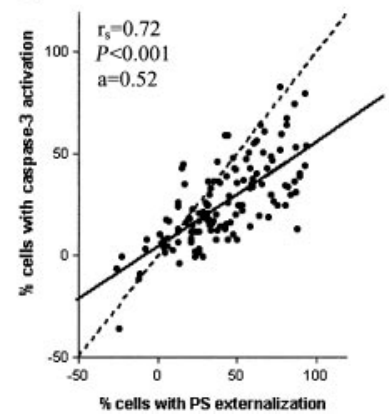

C

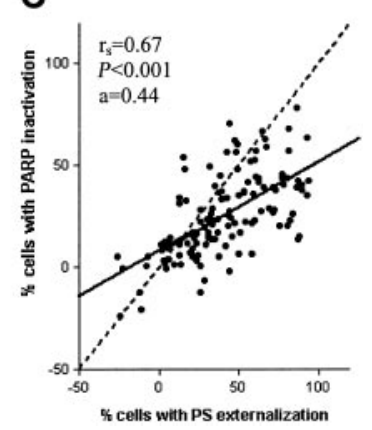

Figure 3. Correlation between drug-induced apoptotic parameters in pediatric ALL. Correlation between the percentage of cells with PS externalization and $\Delta \Psi_{\mathrm{m}}$ depolarization (A), activated caspase-3 (B), or inactivated PARP $(C)$ in leukemic cells in vitro incubated with prednisolone, vincristine, L-asparaginase, or daunorubicin in 50 children with ALL. The dashed line represent the line $x=y$ and the solid line represents the linear regression line. vincristine and daunorubicin. Likewise, PARP inactivation was inversely correlated to cellular drug resistance for prednisolone $\left(\mathrm{r}_{\mathrm{s}}=-0.58, P=.001\right)$ and $\mathrm{L}$-asparaginase $\left(\mathrm{r}_{\mathrm{s}}=-0.58, P=.001\right)$ only (Table 2).

\section{Discussion}

Cellular drug resistance may reflect disruptions in the apoptotic route. ${ }^{17-24}$ Low caspase- 3 activity has been previously linked to a poor prognosis in adult chronic myelogenous leukemia (CML) ${ }^{28}$ and high levels of caspase- 3 with improved survival in adult acute myeloid leukemia (AML). ${ }^{29}$ In addition, loss of spontaneous caspase- 3 activation in vivo is associated with relapse in adults with ALL. ${ }^{30}$ However, the presence and clinical significance of these disruptions in the apoptotic route have not been studied well in pediatric ALL. In the present study, we have analyzed druginduced activation of apoptotic parameters in leukemic cells taken at initial diagnosis of ALL. PS externalization, $\Delta \Psi_{\mathrm{m}}$ disruption, caspase- 3 activation, and PARP inactivation were measured after in vitro exposure to 4 cytotoxic drugs that form the backbone of ALL therapy: prednisolone, vincristine, L-asparaginase, and daunorubicin.

Time series experiments showed a fast activation of apoptotic parameters for daunorubicin and vincristine and a slower activation

Table 1. Correlation between PS externalization and the downstream apoptotic parameters upon drug exposure in pediatric ALL

\begin{tabular}{|c|c|c|c|}
\hline Drug & $\begin{array}{c}\Delta \psi_{m} \\
\text { depolarization }\end{array}$ & $\begin{array}{l}\text { Caspase-3 } \\
\text { activation }\end{array}$ & $\begin{array}{c}\text { PARP } \\
\text { inactivation }\end{array}$ \\
\hline \multicolumn{4}{|l|}{ Prednisolone } \\
\hline Correlation coefficient & .81 & .76 & .76 \\
\hline$P$ & $<.001$ & $<.001$ & $<.001$ \\
\hline $\mathrm{N}$ & 31 & 29 & 29 \\
\hline \multicolumn{4}{|l|}{ Vincristine } \\
\hline Correlation coefficient & .80 & .56 & .64 \\
\hline$P$ & $<.001$ & $<.001$ & $<.001$ \\
\hline $\mathrm{N}$ & 30 & 32 & 32 \\
\hline \multicolumn{4}{|l|}{ L-asparaginase } \\
\hline Correlation coefficient & .42 & .49 & .56 \\
\hline$P$ & .017 & .006 & .002 \\
\hline $\mathrm{N}$ & 32 & 30 & 29 \\
\hline \multicolumn{4}{|l|}{ Daunorubicin } \\
\hline Correlation coefficient & .63 & .50 & .41 \\
\hline$P$ & $<.001$ & .005 & .029 \\
\hline $\mathrm{N}$ & 29 & 31 & 29 \\
\hline
\end{tabular}

Freshly isolated ALL cells were cultured for 18 hours in the presence of $50 \mu \mathrm{g} / \mathrm{mL}$ vincristine or $2.0 \mu \mathrm{g} / \mathrm{mL}$ daunorubicin or 42 hours in the presence of $250 \mu \mathrm{g} / \mathrm{mL}$ prednisolone or $10 \mathrm{IU} / \mathrm{mL}$ L-asparaginase. Drug-induced activation of apoptotic parameters was determined by flow cytometry. Correlation between apoptotic parameters was calculated using the Spearman rank correlation test. for L-asparaginase and prednisolone (Figure 2). One may speculate that this reflects differences in primary cellular targets of the different drugs. Hypothetically, a cell is likely to respond quickly to the direct damaging effect of daunorubicin and vincristine treatment, that is, DNA damage and microtubule damage, respectively. In contrast, it may take a cell relatively longer to respond to the indirect effects of L-asparaginase and prednisolone treatment, that is, induction of gene expression or depletion of the intracellular stock of the amino acid asparagine.

Our data suggest that PS externalization and disruption of $\Delta \Psi_{\mathrm{m}}$ are both early features of apoptosis induced by 4 structurally unrelated drugs in childhood ALL (Figures 2-3). The spread of data points around the line $\mathrm{x}=\mathrm{y}$ in Figure 3 indicates that in half of the patients, disruption of $\Delta \Psi_{\mathrm{m}}$ appears to precede PS externalization (dots above the line $\mathrm{x}=\mathrm{y}$ ). However, in the other half of the patients, disruption of $\Delta \Psi_{\mathrm{m}}$ follows or coincides with PS externalization. No consensus is reached in literature concerning the sequence of these 2 apoptotic events. Conflicting reports have been published showing that disruption of $\Delta \Psi_{\mathrm{m}}$ either preceded or coincided with or followed PS externalization. ${ }^{31-34}$ An explanation for this phenomenon is proposed by Denecker et al, ${ }^{33}$ who suggest that both $\Delta \Psi_{\mathrm{m}}$ disruption and PS externalization are not necessarily 2 dependent but rather parallel events initiated after an apoptotic stimulus. Consequently, the sequence of these 2 apoptotic events may be cell type-, stimulus-, and apparently also patient-specific.

The present data show that resistance of leukemic cells to each of 4 unrelated drugs is associated with decreased PS externalization and $\Delta \Psi_{\mathrm{m}}$ depolarization compared with sensitive cells. Caspase-3 activation or PARP inactivation was linked to cellular resistance to prednisolone and L-asparaginase, but not with cellular resistance toward vincristine and daunorubicin (Table 2). A possible explanation for this observation is that caspase- 3 and PARP cleavage may be an epiphenomenon, which is not essential for vincristine- and daunorubicin-induced apoptosis. Multiple caspases, which are redundant in function, are expressed in acute leukemic cells. ${ }^{35}$ Possibly, in case of vincristine- and daunorubicin-induced apoptosis, a caspase other than caspase- 3 may function as the main effector caspase in primary ALL cells.

We found that cellular drug resistance is associated with decreased PS externalization and $\Delta \Psi_{\mathrm{m}}$ depolarization compared with sensitive cells. Decreased activation of these apoptotic parameters is likely to result from a defect upstream or at the level of both PS externalization and disruption of $\Delta \Psi_{\mathrm{m}}$ (Figure 5). Aberrations in the expression of various molecules associated with cellular drug resistance in mainly adult leukemia and cell lines have been described in literature. ${ }^{36-49}$ Treatment with chemotherapeutic drugs increases intracellular ceramide levels. ${ }^{36}$ Significantly reduced ceramide levels have been linked to drug resistance in adult 
Figure 4. Drug-induced apoptosis inversely correlates with cellular drug resistance in pediatric ALL. Freshly isolated ALL cells were incubated in the presence of vincristine (B) or daunorubicin (D) for 18 hours or prednisolone $(\mathrm{A})$ or L-asparaginase $(\mathrm{C})$ for 42 hours at $37^{\circ} \mathrm{C}$ in a humidified incubator in $5 \% \mathrm{CO}_{2}$. See Figure 2 for drug concentrations used. Each dot corresponds to a patient with ALL.
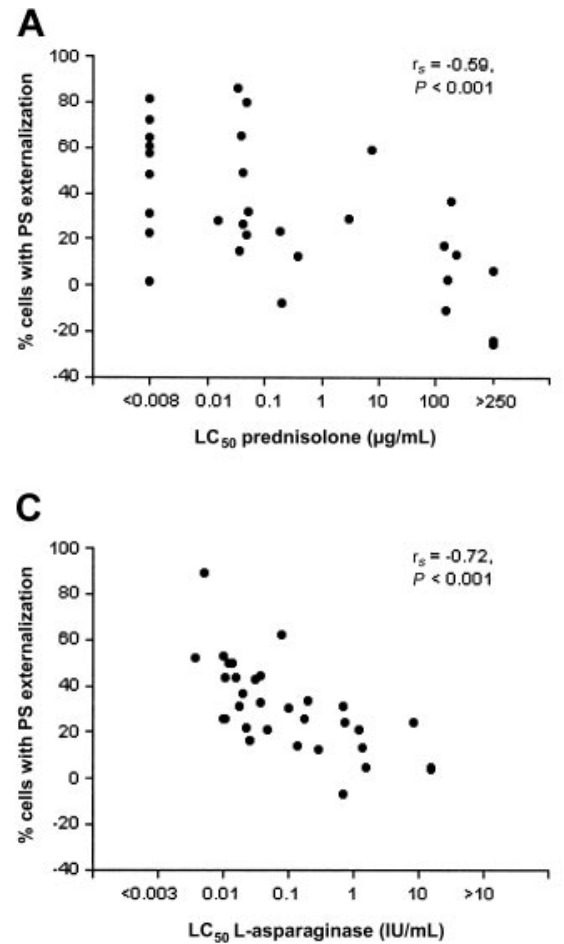
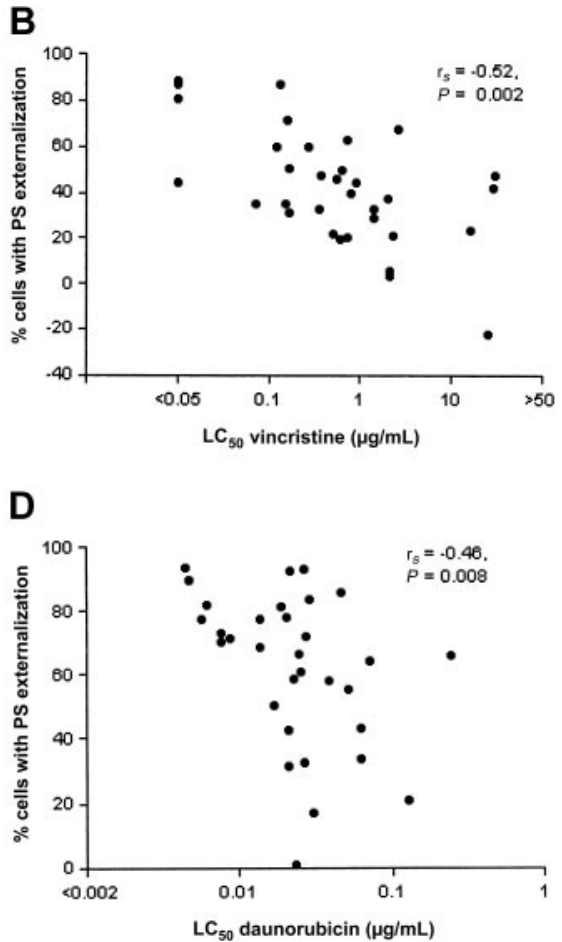

patients with ALL, CML, and AML. ${ }^{37}$ Deficient up-regulation of CD95 ligand and down-regulation of CD95 receptor expression has been shown to confer drug resistance in leukemic cell lines. ${ }^{6,38}$ Aberrant expression of both anti- and proapoptotic Bcl-2 family members is known to prevent mitochondrial permeability transition pore opening and release of apoptogenic proteins from mitochondria. ${ }^{39}$ Data regarding the role of the expression levels of Bcl-2

Table 2. Inverse correlation between cellular drug resistance and the activation of parameters along the effector route of apoptosis in pediatric ALL

\begin{tabular}{ccccc}
\hline $\begin{array}{c}\text { Apoptotic } \\
\text { parameter }\end{array}$ & $\begin{array}{c}\mathrm{LC}_{50} \\
\text { prednisolone }\end{array}$ & $\begin{array}{c}\mathrm{LC}_{50} \\
\text { vincristine }\end{array}$ & $\begin{array}{c}\mathrm{LC}_{50} \\
\text { L-asparaginase }\end{array}$ & $\begin{array}{c}\mathrm{LC}_{50} \\
\text { daunorubicin }\end{array}$ \\
\hline $\begin{array}{c}\text { PS externalization } \\
\text { Correlation }\end{array}$ & & & & \\
$\quad$ coefficient & -.59 & -.52 & -.72 & -.46 \\
$P$ & $<.001$ & .002 & $<.001$ & .008 \\
$\mathrm{~N}$ & 32 & 33 & 32 & 32 \\
$\Delta \psi_{\mathrm{m}}$ depolari- & & & & \\
$\quad$ zation & & & & -.54 \\
Correlation & & & & \\
$\quad$ coefficient & -.43 & -.45 & -.45 & .002 \\
$P$ & .016 & .014 & .010 & 29 \\
$\mathrm{~N}$ & 31 & 30 & 32 &
\end{tabular}

Caspase-3

$\begin{array}{lllll}\begin{array}{l}\text { activation } \\ \text { Correlation } \\ \text { coefficient }\end{array} & -.60 & -.28 & -.46 & -.27 \\ P & .001 & .118 & .011 & .146 \\ \mathrm{~N} & 29 & 32 & 30 & 31\end{array}$

\section{PARP inacti-}

vation

Correlation

\begin{tabular}{ccccc} 
coefficient & -.58 & -.34 & -.58 & -.27 \\
$P$ & .001 & .059 & .001 & .160 \\
$\mathrm{~N}$ & 29 & 32 & 29 & 29 \\
\hline
\end{tabular}

See legend of Table 1. family members and clinical outcome in ALL are contradictory. ${ }^{40-43}$ Overexpression of the p53 regulator MDM2 has been associated with early relapse, adriamycin resistance, and failure to respond to reinduction therapy in childhood leukemia. ${ }^{44}$ In addition, constitutive activation of antiapoptotic proteins such as both $\mathrm{Akt} / \mathrm{PKB}^{45}$ and $\mathrm{c}-\mathrm{Raf}^{46}$ as well as inactivation of the proapoptotic protein PTEN $^{47}$ have been linked to drug resistance in various types of cancers. Other proteins whose overexpression is associated with resistance to apoptosis in acute leukemia are members of the heat shock protein family, including Hsp2 $27^{48}$ and Hsp70.49 To find out (1) which molecules play an actual role in cellular drug resistance in children with ALL and (2) whether resistance to different drugs is associated with drug-specific defects, we currently perform gene expression studies using high-density oligonucleotide microarrays.

In conclusion, the present study shows that decreased PS externalization and $\Delta \Psi_{\mathrm{m}}$ depolarization are found in children with ALL who are in vitro-resistant to structurally unrelated drugs. These data suggest that cellular resistance to these drugs is caused by defects upstream or at the level of mitochondrial function.

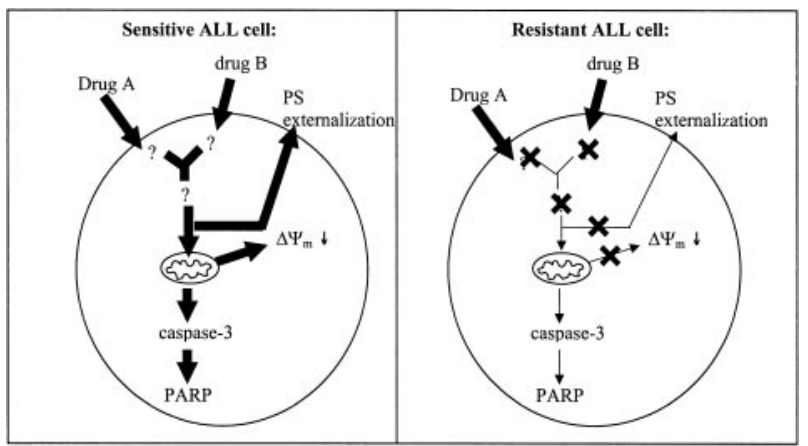

Figure 5. Impaired apoptosis in resistant compared with sensitive ALL cells. A defect localized upstream of the mitochondria may lead to decreased activation of downstream apoptotic parameters in resistant patients with ALL. Potential sites of defects are indicated with a cross. Decreased activation of apoptotic parameters is illustrated by the decreased size of the arrows in resistant compared with sensitive patients. 
Caspase- 3 activation and PARP inactivation are suggested to play a role in prednisolone- and L-asparaginase-induced apoptosis, but are not essential to vincristine- and daunorubicin-induced apoptosis. The nature of the defects upstream or at the level of PS externalization and $\Delta \Psi_{\mathrm{m}}$ depolarization in resistant cells of children with ALL are not elucidated and will be the subjects of further research.

\section{Acknowledgments}

All hospitals involved in the COALL study are gratefully acknowledged for the supply of bone marrow and peripheral blood samples from patients with ALL.

\section{References}

1. Greaves M. Childhood leukaemia. BMJ. 2002 324:283-287.

2. Pieters $\mathrm{R}$, Huismans DR, Loonen $\mathrm{AH}$, et al. Relation of cellular drug resistance to long-term clinical outcome in childhood acute lymphoblastic leukaemia. Lancet. 1991;338:399-403.

3. Kaspers GJ, Pieters R, Van Zantwijk CH, et al. Prednisolone resistance in childhood acute lymphoblastic leukemia: vitro-vivo correlations and cross-resistance to other drugs. Blood. 1998;92: 259-266.

4. Pieters R, den Boer ML, Durian M, et al. Relation between age, immunophenotype and in vitro drug resistance in 395 children with acute lymphoblastic leukemia-implications for treatment of infants. Leukemia. 1998;12:1344-1348.

5. Sen S, D'Incalci M. Apoptosis: biochemical events and relevance to cancer chemotherapy. FEBS Lett. 1992;307:122-127.

6. Friesen C, Herr I, Krammer PH, Debatin KM. Involvement of the CD95 (APO-1/Fas) receptor/ ligand system in drug-induced apoptosis in leukaemic cells. Nat Med. 1996;2:574-577.

7. Eischen CM, Kottke TJ, Martins LM, et al. Comparison in wild-type and Fas-resistant cells: chemotherapy-induced apoptosis is not dependent on Fas/Fas ligand interactions. Blood. 1997; 90:935-943.

8. Hannun YA. Apoptosis and the dilemma of cancer chemotherapy. Blood. 1997;89:1845-1853.

9. Solary E, Droin N, Bettaieb A, et al. Positive and negative regulation of apoptotic pathways by cytotoxic agents in hematological malignancies. Leukemia. 2000;14:1833-1849.

10. Dragovich T, Rudin CM, Thompson CB. Signal transduction pathways that regulate cell survival and cell death. Oncogene. 1998;17:3207-3212.

11. Green DR, Reed JC. Mitochondria and apoptosis. Science. 1998;281:1309-1312.

12. Castedo M, Macho A, Zamzami N, et al. Mitochondrial perturbations define lymphocytes undergoing apoptotic depletion in vivo. Eur J Immu nol. 1995;25:3277-3284

13. Li P, Nijhawan D, Budhihardjo I, et al. Cytochrome $c$ and dATP-dependent formation of Apaf1/caspase-9 complex initiates an apoptotic protease cascade. Cell. 1997:91:479-489.

14. Srinivasula SM, Ahmad M, Fernandes-Alnemri T, Alnemri ES. Autoactivation of procaspase- 9 by Apaf-1-mediated oligomerization. Mol Cell. 1998; 1:949-957.

15. Earnshaw WC, Martins LM, Kaufmann SH. Mammalian caspases: structure, activation, substrates, and functions during apoptosis. Annu Rev Biochem. 1999;68:383-424.

16. Nicholson DW. Caspase structure, proteolytic substrates, and function during apoptotic cell death. Cell Death Differ. 1999;6:1028-1042.

17. Raisova M, Bektas M, Wieder T, et al. Resistance to CD95/Fas-induced and ceramide-mediated apoptosis of human melanoma cells is caused by a defective mitochondrial cytochrome $\mathrm{c}$ release. FEBS Lett. 2000;473:27-32.

18. Kojima $\mathrm{H}$, Endo $\mathrm{K}$, Moriyama $\mathrm{H}$, et al. Abrogation of mitochondrial cytochrome $\mathrm{c}$ release and caspase-3 activation in acquired multidrug resistance. J Biol Chem.1998;273:16647-16650.

19. Wolf BB, Schuler M, Li W, et al. Defective cytochrome c-dependent caspase activation in ovarian cancer cell lines due to diminished or absent apoptotic protease activating factor-1 activity. J Biol Chem. 2001;276:34244-34251.

20. Jia L, Srinivasula SM, Liu F, et al. Apaf-1 protein deficiency confers resistance to cytochrome cdependent apoptosis in human leukemic cells. Blood. 2001;98:414-421.

21. Soengas MS. Inactivation of the apoptosis effec tor apaf-1 in malignant melanoma. Nature. 2001; 409:207-211.

22. Martinez-Lorenzo MJ, Gamen S, Etxeberria J, et al. Resistance to apoptosis correlates with a highly proliferative phenotype and loss of Fas and CPP32 (caspase-3) expression in human leukemia cells. Int J Cancer. 1998;75:473-481.

23. Eggert A, Grosser MA, Suzan TJ, et al. Resistance to tumor necrosis factor-related apoptosisinducing ligand (TRAIL)-induced apoptosis in neuroblastoma cells correlates with a loss of caspase-8 expression. Cancer Res. 2001;61: 1314-1319.

24. Meinhardt G, Roth J, Totok G, Auner H, Emmerich $B$, Hass R. Signalling defect in the activation of caspase- 3 and PKC $\delta$ in human leukemia cells is associated with resistance to apoptosis. Exp Cell Res. 1999;247:534-542.

25. Pieters R, Loonen AH, Huismans DR, et al. In vitro drug sensitivity of cells from children with leukemia using the MTT assay with improved culture conditions. Blood. 1990;76:2327-2336.

26. Pieters R, Huismans DR, Leyva A, Veerman AJ. Adaptation of the rapid automated tetrazolium dye based (MTT) assay for chemosensitivity testing in childhood leukemia. Cancer Lett. 1988:41: 323-332.

27. Chen LB. Mitochondrial membrane potential in living cells. Annu Rev Cell Biol. 1988;4:155-181.

28. Ravandi F, Kantarjian HM, Talpaz M, et al. Expression of apoptosis proteins in chronic myelogenous leukemia: associations and significance. Cancer. 2001;91:1964-1972.

29. Estrov Z, Thall PF, Talpaz M, et al. Caspase 2 and caspase 3 protein levels as predictors of survival in acute myelogenous leukemia. Blood. 1998;92: 3090-3097.

30. Faderl S, Thall PF, Kantarjian HM, et al. Caspase 2 and caspase 3 as predictors of complete remis sion and survival in adults with acute lymphoblastic leukemia. Clin Cancer Res. 1999;5:4041 4047.

31. Castedo M, Hirsch T, Susin SA, et al. Sequential acquisition of mitochondrial alterations during early lymphocyte apoptosis. J Immunol. 1996 157:512-521.

32. Backway KL, McCulloch EA, Chow S, Hedley DW. Relationship between the mitochondrial permeability transition and oxidative stress during ara-C toxicity. Cancer Res. 1997;75:2446-2452.

33. Denecker G, Dooms H, Van Loo G, et al. Phosphatidyl serine exposure during apoptosis precedes release of cytochrome $\mathrm{c}$ and decrease in mitochondrial transmembrane potential. FEBS Lett. 2000;465:47-52.
34. Kluck RM, Bossy-Wetzel E, Green DR, Newmeyer DD. The release of cytochrome c from mitochondria: a primary site for $\mathrm{Bcl}-2$ regulation of apoptosis. Science. 1997;275:1132-1136.

35. Svingen PA, Karp JE, Krajewski S, et al. Evaluation of Apaf-1 and procaspase-2, -3, -7, -8, -9 as potential prognostic markers in acute leukemia. Blood. 2000:96:3922-3931.

36. Hannun YA. Functions of ceramide in coordinating cellular responses to stress. Science. 1996; 274:1855-1859.

37. Itoh M, Kitano T, Watanabe M. Possible role of ceramide as an indicator of chemoresistance: decrease of the ceramide content via activation of glucosylceramide synthase and sphingomyelin synthase in chemoresistant leukaemia. Clin Cancer Res. 2003;9:415-423.

38. Friesen C, Fulda S, Debatin KM. Deficient activation of the CD95 (APO-1/Fas) system in drugresistant cells. Leukemia. 1997;11:1833-1841.

39. Reed JC. Dysregulation of apoptosis in cancer. J Clin Oncol. 1999;17:2941-2953.

40. Coustan-Smith E, Kitanaka A, Pui CH, et al. Clinical relevance of BCL-2 overexpression in childhood acute lymphoblastic leukemia. Blood. 1996; 87:1140-1146.

41. Uckun FM, Yang Z, Sather H, et al. Cellular expression of antiapoptotic BCL-2 oncoprotein in newly diagnosed childhood acute lymphoblastic leukemia: a Children's Cancer Group study. Blood. 1997;89:3769-3777.

42. Hogarth LA, Hall AG. Increased BAX expression is associated with an increased risk of relapse in childhood acute lymphoblastic leukemia. Blood. 1997;93:2671-2678.

43. Prokop A, Wieder T, Sturm I, et al. Relapse in childhood acute lymphoblastic leukaemia is associated with a decrease of the $\mathrm{Bax} / \mathrm{Bcl}-2$ ratio and loss of spontaneous caspase- 3 processing in vivo. Leukemia. 2000;14:1606-1613.

44. Zhou M, Gu L, Abshire TC. Incidence and prognostic significance of MDM2 oncoprotein overexpression in relapsed childhood acute lymphoblastic leukemia. Leukemia. 2000:61-67.

45. Brognard J, Clark AS, Ni Y, Dennis PA. Akt/protein kinase $B$ is constitutively active in non-smal cell lung cancer cells and promotes cellular survival and resistance to chemotherapy and radiation. Cancer Res. 2001;61:3986-3997.

46. Lau QC, Brusselbach S, Muller R. Abrogation of c-Raf expression induces apoptosis in tumor cells. Oncogene. 1998;16:1899-1902.

47. Sakai A, Thieblemont C, Wellmann A, Jaffe ES, Raffeld M. PTEN gene alterations in lymphoid neoplasms. Blood. 1998;92:3410-3415.

48. Kasimir-Bauer S, Beelen D, Flasshove M, et al. Impact of the expression of $\mathrm{P}$ glycoprotein, the multidrug resistance-related protein, bcl-2, mutant p53, and heat shock protein 27 on response to induction therapy and long-term survival in patients with de novo acute myeloid leukemia. Exp Hematol. 2002;30:1302-1308.

49. Chant ID, Rose PE, Morris AG. Susceptibility of AML cells to in vitro apoptosis correlates with heat shock protein 70 (hsp 70) expression. $\mathrm{Br} \mathrm{J}$ Haematol. 1996;93:898-902. 